\title{
UJI PREFERENSI KONSUMEN PADA KARAKTERISTIK ORGANOLEPTIK PRODUK ROTI GANDUM UTUH DI KOTA MALANG JAWA TIMUR
}

\section{Consumer Preference Test on Organoleptic Characteristics of Whole Wheat Bread Products in Malang City East Java}

\author{
Jaya Mahar Maligan ${ }^{1,2 *}$, Firdanita Salsabella ${ }^{1}$, Siti Narsito Wulan ${ }^{1}$ \\ 1) Jurusan Teknologi Hasil Pertanian, FTP Universitas Brawijaya Malang, Jl. Veteran, \\ Malang 65145 \\ 2) Pusat Studi Pengembangan Pangan Lokal, Universitas Brawijaya, Jl. Veteran, Malang \\ 65145 \\ *Penulis Korespondensi, Email: maharajay@gmail.com
}

\begin{abstract}
ABSTRAK
Persaingan industri toko roti yang memproduksi roti gandum utuh dinilai cukup ketat sehingga produsen harus bersaing untuk menarik minat konsumen agar membeli produk yang dijual. Oleh karena itu, para pelaku industri bakery harus mengetahui preferensi dan keinginan konsumen terhadap roti gandum utuh untuk meningkatkan penjualan dan minat konsumen. Tujuan dari penelitian ini adalah untuk mengetahui dan menganalisis perbedaan preferensi konsumen terhadap karakteristik organoleptik 6 merek roti gandum utuh yang dijual di Kota Malang. Analisis data organoleptik dilakukan menggunakan metode Analysis of Variance (ANOVA) General Linear Mode (GLM) dengan uji lanjut Tukey. Hasil penelitian menunjukkan bahwa perbedaan merek berpengaruh signifikan terhadap preferensi konsumen pada karakteristik organoleptik warna, aroma, rasa, tekstur dan kenampakan produk roti gandum utuh.

Kata Kunci : Preferensi Konsumen, Roti Gandum Utuh, Uji organoleptik.

\section{ABSTRACT}

Competition in the bakery industry that produces whole wheat bread is considered to be quite tight, so producers must compete to attract consumers to buy their products. Therefore, the bakery industry must know the needs and desires of consumers for wheat bread to increase sales and consumer interest. The purpose of this study was to find out and analyze differences in consumer preferences towards organoleptic characteristics and differences in the physical properties of wheat bread products sold in Malang City. Organoleptic and physical data analysis was carried out using the Analysis of Variance (ANOVA) General Linear Mode (GLM) method with Tukey's advanced test. The results showed that consumer preferences significantly affected the sensory attributes of color, aroma, taste, texture and appearance of whole wheat bread products.
\end{abstract}

Keywords : Consumer Preference, Whole Wheat Bread, Organoleptic Test 


\section{PENDAHULUAN}

Kesadaran manusia dalam menjaga kualitas kesehatan semakin meningkat setiap tahunnya. Salah satu upaya dalam menjaga kesehatan tubuh yaitu dengan mengonsumsi makanan yang sehat dengan kandungan rendah gula dan tinggi serat, salah satunya terdapat pada olahan makanan berbahan dasar gandum yaitu roti gandum utuh. Menurut Zakaria (2007), roti gandum utuh berbahan dasar dari biji gandum yang telah melalui proses penggilingan dan pengayakan seperti tepung terigu, namun tidak dimurnikan sehinga tepung gandum utuh berwarna cokelat. Persaingan industri toko roti yang memproduksi roti gandum utuh dinilai cukup ketat sehingga produsen harus bersaing untuk menarik minat konsumen agar membeli produk yang dijual. Peneliti telah melakukan survey terhadap 50 buah toko roti yang tersebar pada lima kecamatan di Kota Malang, sedangkan dari banyaknya toko roti tersebut terdapat 21 buah toko yang memproduksi roti gandum utuh. Oleh karena itu, para pelaku industri bakery harus mengetahui kebutuhan dan keinginan konsumen terhadap roti gandum untuk meningkatkan penjualan dan minat konsumen. Tujuan dari penelitian ini adalah untuk mengetahui dan menganalisis perbedaan preferensi konsumen terhadap atribut sensori dan perbedaan sifat fisik produk roti gandum yang dijual di Kota Malang.

\section{BAHAN DAN METODE}

\section{Bahan}

Bahan yang digunakan dalam penelitian ini adalah sampel roti gandum utuh yang diperoleh dari 6 toko roti yang berada di Kota Malang yang diberi kode sampel yaitu FPB, HLB, DBC, PSB, KRT, dan MYB. Bahan tambahan yang diperlukan dalam penelitian ini adalah air mineral $240 \mathrm{ml}$ yang digunakan untuk menetralkan indera pengecap para panelis pada saat uji organoleptik dilakukan.

\section{Alat}

Alat yang digunakan pada pengujian organoleptik ada penelitian ini antara lain yaitu bilik uji, gelas air mineral $240 \mathrm{ml}$, wadah sampel, label, lembar kuisioner, pena, kursi, dan tempat pembuangan sampah.

\section{Penentuan Sampel dan Panelis}

Berdasarkan penelitian pendahuluan yang telah dilaksanakan diperoleh sebanyak 21 toko roti di Kota Malang yang menjual produk roti gandum utuh yang tersebar pada 3 kecamatan, yaitu kecamatan Klojen, Sukun, dan Lowokwaru. Sampel tersebut dilakukan sampling dengan teknik sampling acak berstrata pada tiap kecamatan untuk memilih sampel berdasarkan kebutuhan. Hasil yang diperoleh dari sampling tersebut yaitu terpilih 6 toko yang menjual roti gandum utuh di Kota Malang yaitu merek FPB, HLB, DBC, PSB, KRT dan MYB. Sejumlah 100 orang panelis dipilih dengan teknik accidental sampling yang merupakan mahasiswa maupun mahasiswi yang berada di Kota Malang dengan rentang usia 19 - 23 tahun.

\section{Pengambilan Data}

Data pada penelitian ini diambil berdasarkan hasil dari uji organoleptik dan uji fisik pada produk roti gandum utuh yang telah dilakukan. Pada uji organoleptik dilakukan dengan uji hedonik dengan parameter yang digunakan meliputi atribut kenampakan, warna, rasa, aroma, dan tekstur. 


\section{Analisis Data}

Metode uji organoleptik yang digunakan adalah Hedonic Scale Scoring. Data uji organoleptik dan fisik yang diperoleh diuji menggunakan uji normalitas menggunakan metode Kolmogorov Smirnov pada aplikasi Minitab 17. Hasil uji normalitas data yang normal dilakukan analisis menggunakan metode ANOVA General Linear Model (GLM) pada aplikasi Minitab 17 dengan selang kepercayaan 95\%. Apabila hasil uji menunjukkan pengaruh yang nyata, maka dilakukan uji lanjut Tukey. Hasil uji normalitas data yang tidak normal kemudian dianalisis menggunakan uji nonparametrik Friedman dengan selang kepercayaan 95\% pada aplikasi Minitab 17, dan apabila hasil uji menunjukkan pengaruh yang nyata, maka dilakukan uji lanjut Perbandingan Berganda.

\section{HASIL DAN PEMBAHASAN}

\section{Karakteristik Responden}

Karakteristik umum responden konsumen roti gandum adalah mahasiswa di Kota Malang yang pernah membeli roti gandum dengan frekuensi pembelian satu kali maupun lebih dari satu kali dalam taraf merek produsen yang tidak sama. Responden yang dituju merupakan responden dari segala usia dengan kelompok usia 19 - 23 tahun. Populasi responden yang digunakan dalam penelitian kali ini berjumlah 100 responden. Data karakteritik responden dapat dilihat pada Tabel 1.

\begin{tabular}{cccc}
\multicolumn{2}{c}{ Tabel 1. Karakteristik Responden } & \multicolumn{2}{c}{ Frekuensi } \\
\hline No & \multicolumn{1}{c}{ Kategori } & $\mathbf{n}$ & $\%$ \\
\hline 1. Jenis Kelamin & & \\
& Perempuan & 62 & 62 \\
& Laki-laki & 38 & 38 \\
& Total & 100 & 100 \\
2. Usia (tahun) & & \\
19 & 8 & 8 \\
& 16 & 16 \\
20 & 36 & 36 \\
21 & 28 & 28 \\
22 & 12 & 12 \\
23 & 100 & 100 \\
\hline
\end{tabular}

Tabel 1. menunjukkan bahwa jumlah responden pada setiap kategori usia tidak merata dimana 36\% responden berusia 21 tahun dan sebesar $8 \%$ responden berusia 19 tahun. Responden pada penelitian ini adalah mahasiswa di Kota Malang dengan rentang usia 19 - 23 tahun. Penelitian ini menggunakan metode non probability sampling dan dilakukan pada lingkungan kampus dimana responden pada usia tersebut lebih banyak dijumpai.

\section{Tingkat Kesukaan Terhadap Warna Crumb}

Hasil rerata nilai kesukaan panelis terhadap atribut warna pada roti gandum utuh dapat dilihat pada Tabel 2. 
Uji Preferensi Konsumen pada Karakteristik Organoleptik - Maligan, dkk Jurnal Pangan dan Agroindustri Vol.6 No.4: 70-76, Oktober 2018

Tabel 2. Perbedaan Rerata Kesukaan Terhadap Warna Crumb Antar Sampel

\begin{tabular}{ccc}
\hline Sampel & $\begin{array}{c}\text { Rerata Kesukaan } \\
\text { Terhadap Warna Crumb }\end{array}$ & Kriteria Nilai Rerata \\
\hline MYB & $3,82 \pm 0,91 \mathrm{a}$ & Cukup Suka \\
KRT & $3,75 \pm 0,73 \mathrm{a}$ & Cukup Suka \\
HLB & $3,56 \pm 0,77 \mathrm{ab}$ & Cukup Suka \\
FPB & $3,50 \pm 0,77 \mathrm{ab}$ & Cukup Suka \\
PSB & $3,32 \pm 0,95 \mathrm{~b}$ & Cukup Suka \\
DBC & $2,72 \pm 1,20 \mathrm{c}$ & Tidak Suka \\
\hline
\end{tabular}

Hasil sidik ragam menunjukkan bahwa perbedaan warna roti gandum utuh pada sampel roti gandum berpengaruh nyata terhadap tingkat kesukaan panelis. Panelis memilih sampel MYB sebagai sampel dengan rerata nilai warna tertinggi dapat dikarenakan sampel tersebut dianggap memiliki warna yang sesuai dengan preferensi panelis mengenai roti gandum utuh. Sampel MYB memiliki warna sampel yaitu coklat sedikit muda sehingga dimungkinkan panelis menyukai produk MYB karena memiliki warna yang dianggap lebih cerah dibandingkan produk lainnya. Sampel dengan nilai rerata warna terendah yang dipilih oleh panelis adalah sampel DBC. Hal ini dapat dikarenakan sampel DBC dianggap memiliki warna yang kurang sesuai dengan preferensi panelis mengenai roti gandum utuh. Sampel DBC terlihat memiliki warna yang lebih gelap dan lebih coklat dari sampel lainnya sehingga dimungkinkan panelis kurang menyukai sampel DBC karena dianggap gosong. Warna dapat memengaruhi nilai kesukaan produk dan produk yang berwarna tidak sesuai sering mendapatkan nilai penerimaan yang rendah (Mahony, 2001).

\section{Tingkat Kesukaan Terhadap Aroma}

Hasil rerata nilai kesukaan panelis terhadap atribut aroma pada roti gandum utuh dapat dilihat pada Tabel 3.

Tabel 3. Perbedaan Rerata Kesukaan Terhadap Atribut Aroma Antar Sampel

\begin{tabular}{ccc}
\hline Sampel & $\begin{array}{c}\text { Rerata Kesukaan } \\
\text { Terhadap Aroma Roti }\end{array}$ & Kriteria Nilai Rerata \\
\hline FPB & $3,63 \pm 0,73 \mathrm{a}$ & Cukup Suka \\
PSB & $3,56 \pm 1,08 \mathrm{a}$ & Cukup Suka \\
KRT & $3,19 \pm 0,93 \mathrm{~b}$ & Cukup Suka \\
DBC & $3,16 \pm 1,07 \mathrm{~b}$ & Cukup Suka \\
MYB & $3,12 \pm 0,84 \mathrm{~b}$ & Cukup Suka \\
HLB & $3,08 \pm 0,85 \mathrm{~b}$ & Cukup Suka \\
\hline
\end{tabular}

Hasil sidik ragam menunjukkan bahwa perbedaan aroma roti gandum utuh pada sampel roti gandum berpengaruh nyata terhadap tingkat kesukaan panelis. Panelis memilih sampel FPB sebagai sampel dengan rerata nilai aroma tertinggi. Hal ini dapat dikarenakan sampel FPB dianggap memiliki aroma yang sesuai dengan preferensi panelis mengenai roti gandum utuh. Sampel dengan nilai rerata aroma terendah yang dipilih oleh panelis adalah sampel HLB, dikarenakan sampel HLB dianggap memiliki aroma yang kurang sesuai dengan preferensi panelis mengenai roti gandum utuh. Perbedaan preferensi konsumen 
terhadap aroma sampel dapat dikarenakan perbedaan sensitivitas indra penciuman dan tingkat kesukaan panelis terhadap bahan yang digunakan dalam pembuatan roti gandum utuh. Semakin banyak substitusi tepung gandum utuh, maka aroma roti gandum yang dihasilkan berbeda. Hal ini dikarenakan tepung gandum utuh memiliki aroma yang khas sehingga mempengaruhi aroma roti yang dihasilkan. Menurut Boesveldt dan Graaf (2017), indera penciuman memainkan peran utama dalam perilaku makan seseorang yang telah didemonstrasikan bahwa paparan bau dapat merangsang nafsu makan. Namun, pengaruh aroma pada pemilihan makanan dapat bergantung pada kesadaran, intensitas aroma, dan berdasarkan ciri - ciri kepribadian dari konsumen.

\section{Tingkat Kesukaan Terhadap Rasa}

Hasil rerata nilai kesukaan panelis terhadap atribut rasa pada roti gandum utuh dapat dilihat pada Tabel 4.

Tabel 4. Perbedaan Rerata Kesukaan Terhadap Atribut Rasa Antar Sampel

\begin{tabular}{ccc}
\hline Sampel & $\begin{array}{c}\text { Rerata Kesukaan } \\
\text { Terhadap Rasa Roti }\end{array}$ & Kriteria Nilai Rerata \\
\hline PSB & $3,67 \pm 0,99 \mathrm{~b}$ & Cukup Suka \\
KRT & $3,36 \pm 0,97 \mathrm{~b}$ & Cukup Suka \\
MYB & $3,33 \pm 0,93 \mathrm{ab}$ & Cukup Suka \\
FPB & $3,26 \pm 0,77 \mathrm{ab}$ & Cukup Suka \\
HLB & $3,15 \pm 0,81 \mathrm{ab}$ & Cukup Suka \\
DBC & $2,67 \pm 0,97 \mathrm{a}$ & Tidak Suka \\
\hline
\end{tabular}

Hasil analisis statistik Friedman menunjukkan bahwa perbedaan rasa roti gandum utuh pada sampel roti gandum berpengaruh nyata terhadap tingkat kesukaan panelis. Panelis memilih sampel PSB sebagai sampel dengan rerata nilai rasa tertinggi. Hal ini dapat dikarenakan sampel PSB dianggap memiliki rasa yang sesuai dengan persepsi panelis mengenai roti gandum utuh. Sampel dengan nilai rerata rasa terendah yang dipilih oleh panelis adalah sampel DBC. Hal ini dapat dikarenakan sampel DBC dianggap memiliki rasa yang kurang sesuai dengan preferensi panelis mengenai roti gandum utuh. Menurut pendapat beberapa panelis rasa roti gandum yang dihasilkan oleh sampel PSB memiliki rasa yang cukup unik dikarenakan seperti mengandung rasa mocca dan tidak memiliki rasa gandum yang kuat, serta rasa manis yang cukup. sedangkan produk yang dihasilkan oleh sampel DBC memiliki rasa gandum yang sangat kuat. Rasa roti mengacu pada sensasi manis yang disebabkan oleh kontak mulut dengan agen pemanis yang terdapat pada roti. Karakteristik rasa roti merupakan atribut yang vital dalam menentukan penerimaan keseluruhan produk. Rasa keseluruhan akan berkurang secara signifikan saat tingkat substitusi tepung terigu meningkat. Roti dengan kandungan 10 dan $20 \%$ tepung terigu tidak berbeda secara signifikan ( $p \leq 0,05)$ dalam rasa (Ngozi, 2014).

\section{Tingkat Kesukaan Terhadap Tekstur}

Hasil rerata nilai kesukaan panelis terhadap atribut rasa pada roti gandum utuh dapat dilihat pada Tabel 5. 
Tabel 5. Perbedaan Rerata Kesukaan Terhadap Atribut Tekstur Antar Sampel

\begin{tabular}{ccc}
\hline Sampel & $\begin{array}{c}\text { Rerata Kesukaan } \\
\text { Terhadap Tekstur } \\
\text { Roti }\end{array}$ & $\begin{array}{c}\text { Kriteria Nilai } \\
\text { Rerata }\end{array}$ \\
\hline MYB & $3,61 \pm 0,82 \mathrm{a}$ & Cukup Suka \\
PSB & $3,57 \pm 0,79 \mathrm{a}$ & Cukup Suka \\
FPB & $3,51 \pm 0,75 \mathrm{~b}$ & Cukup Suka \\
KRT & $3,10 \pm 0,85 \mathrm{~b}$ & Cukup Suka \\
HLB & $2,95 \pm 0,85 \mathrm{bc}$ & Tidak Suka \\
DBC & $2,68 \pm 1,14 \mathrm{c}$ & Tidak Suka \\
\hline
\end{tabular}

Hasil sidik ragam menunjukkan bahwa perbedaan tekstur roti gandum utuh pada sampel roti gandum berpengaruh nyata terhadap tingkat kesukaan panelis. Panelis memilih sampel MYB sebagai sampel dengan rerata nilai tekstur tertinggi. Hal ini dapat dikarenakan sampel MYB memiliki tekstur yang sesuai dengan preferensi panelis mengenai roti gandum utuh. Sampel dengan nilai rerata tekstur terendah yang dipilih oleh panelis adalah sampel DBC. Hal ini dapat dikarenakan sampel DBC dianggap memiliki tekstur yang kurang sesuai dengan preferensi panelis mengenai roti gandum utuh. Menurut Wijayanti (2007), perbedaan tingkat kekerasan dipengaruhi oleh volume roti, kadar air, dan shortening. Volume roti yang baik memiliki pengembangan yang diinginkan karena gas yang cukup yang dihasilkan selama fermentasi dan ditahan oleh gluten. Gluten menyebabkan adonan menjadi elastis dan mampu membentuk struktur roti dengan menahan gas. Adanya poripori dalam roti menyebabkan tekstur menjadi lunak. Pengaruh kadar air adalah makin tinggi kadar air, tekstur roti makin lunak, dimana kemampuan mengikat air ditentukan oleh gugus $-\mathrm{OH}$ yang dimiliki oleh protein dan karbohidrat. Sedangkan shortening dapat memperbaiki tekstur, volume, dan kenampakan produk. Dengan demikian, makin tinggi penambahan tepung gandum meningkatkan tingkat kekerasan sebab terjadi penurunan volume roti karena tingkat pengembangan yang menurun dan disebabkan kadar gluten yang berkurang sehingga gas yang dapat ditahan menurun.

\section{Tingkat Kesukaan Terhadap Kenampakan}

Hasil rerata nilai kesukaan panelis terhadap atribut kenampakan pada roti gandum utuh dapat dilihat pada Tabel 6.

Tabel 6. Perbedaan Rerata Kesukaan Terhadap Atribut Kenampakan Antar Sampel

\begin{tabular}{ccc}
\hline Sampel & $\begin{array}{c}\text { Rerata Kesukaan } \\
\text { Terhadap } \\
\text { Kenampakan Roti }\end{array}$ & Kriteria Nilai Rerata \\
\hline MYB & $4,03 \pm 0,94 a$ & Suka \\
HLB & $3,86 \pm 0,90 \mathrm{a}$ & Cukup Suka \\
KRT & $3,70 \pm 0,82 \mathrm{a}$ & Cukup Suka \\
FPB & $3,26 \pm 0,98 \mathrm{~b}$ & Cukup Suka \\
PSB & $3,11 \pm 0,89 \mathrm{~b}$ & Cukup Suka \\
DBC & $3,10 \pm 1,02 \mathrm{~b}$ & Cukup Suka \\
\hline
\end{tabular}

Hasil sidik ragam menunjukkan bahwa perbedaan kenampakan roti gandum utuh pada sampel roti gandum berpengaruh nyata terhadap tingkat kesukaan panelis. Panelis 
memilih sampel MYB sebagai sampel dengan rerata nilai kenampakan tertinggi. Hal ini dapat dikarenakan sampel MYB memiliki kenampakan yang sesuai dengan preferensi panelis mengenai roti gandum utuh. Sampel dengan nilai rerata kenampakan terendah yang dipilih oleh panelis adalah sampel DBC. Hal ini dapat dikarenakan DBC dianggap memiliki kenampakan yang kurang sesuai dengan preferensi panelis mengenai roti gandum utuh. Menurut Campo et al (2017), pendapat seseorang mengenai kenampakan suatu produk dipengaruhi oleh warna dan bentuk dari produk tersebut. Indera penglihatan dapat mempengaruhi indera pengecapan karena kenampakan dari sebuah makanan dapat memberikan rangsangan kepada otak dan memberikan respon harapan mengenai rasa produk tersebut.

\section{SIMPULAN}

Hasil penelitian menunjukkan bahwa perbedaan merek berpengaruh signifikan terhadap preferensi konsumen pada karakteristik organoleptik warna, aroma, rasa, tekstur dan kenampakan produk roti gandum utuh. Sampel MYB memiliki nilai rerata tertinggi pada analisis uji hedonik pada atribut kenampakan, warna, dan tekstur, sedangkan sampel FPB memiliki nilai rerata tertinggi pada atribut aroma, dan sampel PSB memiliki nilai rerata tertinggi pada atribut rasa.

\section{DAFTAR PUSTAKA}

Bakke, A dan Z. Vickers. 2007. Consumer liking of refined and whole wheat breads. J. Food Sci., 72: S473-S480.

Boesveldt, S., \& de Graaf, K. 2017. The Differential Role of Smell and Taste for Eating Behavior. Perception, 46(3-4), 307-319.

Bushuk, W., Rasper V. F., 1994. Wheat: Production, Properties, and Quality. Chapman \& Hall, United Kongdom.

Campo, R., Loporcarco, G., Baldassarre, F. 2017. The Effects of Food Aesthetic on Consumers. Visual Stimuli and Food Marketing. DIEM: Dubrovnik International Economic Meeting (Vol. 3, No. 1, pp. 553-565).

Collar., C Bollaín, C., Angioloni, A. (2005) Bread staling assessment of enzymes supplemented pan breads by dynamic and static deformation measurement. European Food Research and Technology, 220, 83-89.

Mahony, A. 2001. Effect of Color on The Odor, Flavor, and Acceptance Properties of Foods And Beverages. Kansas State University. Manhattan.

Ngozi, A.A. 2014. Effect of Whole Wheat Flour on the Quality of Wheat-Baked Bread. Global Journal of Food Science and Technology, Vol. 2 (3):127- 133.

Ronzio, R. 2003. The Encyclopedia of Nutrition and Good Health. Facts On File, Inc. New York.

Wijayanti. 2007. Subtitusi Tepung Gandum (Triticum aestivum) Dengan Tepung Garut (Maranta arundinaceaeL) Pada Pembuatan Roti Tawar. Skripsi. Teknologi Pertanian Universitas Gajah Mada. Yogyakarta.

Zakaria, F.R., 2007. Makanan Utuh (Whole Foods) Untuk Konsumen Cerdas. bpkn.go.id. 